\title{
Effects of Parental Socioeconomic Status on the Academic Achievement of Secondary School Students in Karak District, Pakistan
}

\author{
Qaiser Suleman \\ M.Phil (Education) Scholar, Institute of Education \& Research, Kohat University of Science \\ \& Technology, Khyber Pakhtunkhwa, (Pakistan) \\ Email: Look_for_reality@yahoo.com
}

Dr. Ishtiaq Hussain

Assistant Professor, Institute of Education \& Research, Kohat University of Science \& Technology, Khyber Pakhtunkhwa, (Pakistan)

Email: dr.ishtiaqkust@gmail.com

Farid Ullah Khan

Lecturer, Institute of Education \& Research, Kohat University of Science \& Technology, Khyber Pakhtunkhwa, (Pakistan)

\section{Zaib-un-Nisa}

M.Phil (Education) Scholar, Institute of Education \& Research, Kohat University of Science \& Technology, Khyber Pakhtunkhwa, (Pakistan)

Accepted: August 05, 2012 Published: October 09, 2012

Doi:10.5296/ijhrs.v2i4.2511 URL: http://dx.doi.org/10.5296/ijhrs.v2i4.2511

\begin{abstract}
The purpose of this research work was to investigate the effects of parental socioeconomic status on the academic achievement of secondary school students. All the students studying at secondary school level in Karak District, Khyber Pakhtunkhwa (Pakistan) constituted the population of the study. The study was delimited to only sixty government boys' high schools in Karak District. The study was further delimited to the students of $10^{\text {th }}$ Class. In order to represent adequate representation of the population, 1500 secondary school students were selected through simple random sampling technique. The study was survey type and therefore a self-developed structured questionnaire was used for the collection of data. Data was collected through personal visits. After collection of data, it was organized, tabulated and analyzed. Chi-square and percentage were used for the statistical analysis of the data. After statistical analysis of data, the researchers concluded that parental socio-economic status; parent's educational level, parental occupational level; and parental income level affect the academic achievement of secondary school students. Based on findings, it was suggested that
\end{abstract}


unemployment should be controlled. Poor students should be provided scholarships, free books and other stationary. In addition, it was also recommended that government should take steps to raise socioeconomic status of people.

Keywords: Parental Socioeconomic Status, Academic Achievement, Secondary School Students

\section{Introduction}

Socioeconomic status is a definite background variable that represents a feature of the social structure in society (Oakes \& Rossi, 2003). It is a fact that families where the parents are privileged educationally, socially and economically, promote a higher level of achievement in their offspring. They also give higher levels of psychological support for their children through enriched atmosphere that promote and encourage the development of skills required for success at school (Williams, $1987 \&$ Williams et al., 1993). The socioeconomic status of a child is usually determined by parental educational level, parental occupational status and income level (Jeynes 2002). It is understood that low socioeconomic status negatively and depressingly affects students' academic achievement because due to low socioeconomic status, a student does not access to important resources and generates additional stress and tension at home (Eamon, 2005; Jeynes, 2002). According to Parson, Stephanie and Deborah (2001), socioeconomic status is an expression which is used to differentiate between people's relative status in the community regarding family income, political power, educational background and occupational status. Saifi and Mehmood (2011) state that socioeconomic status is a combined measure of economic and social position of an individual or family relative to others on the basis of income, education and occupation.

Suleman et al. (2012) found that that those children whose socioeconomic status was strong show better academic performance and those with poor socioeconomic status showed poor and unsatisfactory academic performance. Heyneman (2005) stated that for many years researches have revealed that students do not show effective performance in school whose parental socioeconomic status is low. The academic achievement of students is negatively correlated with the low parental socioeconomic status level as it prevents the individual in gaining access to sources and resources of learning (Duke, 2000 \& Eamon, 2005). Most of the researchers and experts believed that the low socioeconomic status negatively affect the academic performance of students because due to low socioeconomic status their needs and demands remain unfulfilled and that is why they do not show better academic performance (Adams, 1996). Farooq et al. (2011) concluded that the higher level of socioeconomic status is the best indicator which plays a fundamental role in promoting quality of students' achievement.

The current paper was designed to explore the effects of parental socioeconomic status on the academic achievement of secondary school students. The researchers expect that this study will be useful for secondary school students and their parents as it will suggest some remedial measures for the effective and better academic performance of the secondary 
school students.

\section{Review of Related Literature}

Socioeconomic status is the combination of economic and sociological measures of an individual work experience and the economic and social position of an individual or family in relation to others on the basis of income, educational level and occupational status. For the analysis of a family socioeconomic status, the household income, education of earner and occupation are checked as well as combined income compared with an individual, when their own attributes are assessed. Socioeconomic status is generally divided into three categories i.e., high socioeconomic status, middle socioeconomic status and low socioeconomic to explain the three fields a family or an individual may fall into. When putting a family or individual into one of these categories, any or all of the three variables i.e., income, education, and occupation can be reviewed and assessed (Online wikipedia encyclopedia). Socioeconomic status (SES) is assessed as a combination of factors containing income, level of education, and occupation. It is a way of observing to know how individuals or families adjust in society using economic and social measures that have been shown to impact individuals' health and well being.

Different scholars have defined socioeconomic status in different ways. Some scholars consider that socioeconomic status is the total household income while other scholars include other variables i.e., parental educational levels. In addition to the widely used income variable, some others variables are also considered i.e., family and parental educational attainment; total family income; living in poverty; living in a single-parent household; motivation for learning; alcohol or drug use; crime; community/environment; etc. Many scholars consider that socioeconomic status is the most important and fundamental factor which is responsible for the academic success (Coleman 1966; Duncan 2005). Socioeconomic status refers to as a finely graded hierarchy of social positions which can be used to illustrate a person's overall social position or reputation. It can be indicated by a number of concepts such as employment status, occupational status, educational attainment and income and wealth (Graetz, 1995).

Many research studies have shown that the socio-economic status is a factor responsible for the academic attainment of the students. Research studies show that socio-economic status influences student's achievements (Jeynes, 2002; Eamon, 2005; Hochschild, 2003). It is believed that low socio-economic status has significant negative affects on the academic achievement of the students because low socio-economic status is the obstruction to access to very important resources and creates additional tension and stress at home (Eamon 2005; Jeynes 2002). Students who have a low socio-economic status show poor result and are more likely to leave the school (Eamon, 2005; Hochschild 2003). Morakinyo (2003) found that there is a relationship between socio-economic status and academic achievement of the students. White (1986) in a Meta analysis of 620 correlations coefficient from 100 students describes that there is a definite relationship between socioeconomic status and academic achievement of the students. He noted that the frequency 
obtained correlation ranged from 0.10 to 0.70 which is positive relationship. It means that if one factor is increased the other also increases. It is came to surface that those children whose socio-economic status is strong show better academic performance and those with poor socio-economic status show poor and unsatisfactory academic performance. Rouse and Barrow (2006) state that socioeconomic status has significant effects on educational achievements that contain test scores, and continue to affect the child throughout their adulthood. White (1982) states, "The family characteristic that is the most influential predictor of school performance is socioeconomic status; the higher the socioeconomic status of the student's family, the higher his academic achievement". A recent meta-analysis of studies investigating the relationship of socioeconomic status to academic achievement showed that different variables of socioeconomic status e.g., parental education, parental income and parental occupation have different effects on the educational attainment (Sirin, 2005). Kruse (1996) conducted a study to find out whether students from low socioeconomic environments have lower academic achievement compared to the academic achievement of students from higher socioeconomic environments. He arrived at the results that there was a statistically significant difference between the academic achievements of low socioeconomic environments compared to that of high socioeconomic environments.

Parental education is also an important aspect of the socioeconomic status of school students because it is expected that parental and student education is significantly correlated. Peters and Mullis (1997) concluded that parental education had a significant effect on academic achievement of the students. The mother's education level had a $20 \%$ higher affect than the father's education level on the academic achievement of adolescents. According to Eamon (2005), mother education affects the academic achievement of the students. The children of highly educated mothers obtain higher test scores. Caldas and Bankston (1997) found that parental educational background and occupational status had significant effects on academic achievement than family income alone. A number of studies have recommended that parents of higher socioeconomic status are more engaged in their children's education as compared to the parents of lower socioeconomic status and that greater parental participation and involvement promotes more positive attitudes toward school, improves homework habits, reduces absenteeism and dropping out, and enhances academic achievement (Muller, 1993 and Stevenson \& Baker, 1987). An earlier study by James (2002) also showed that parental education levels exposed the clearest patterns of variation in student attitudes towards school and post school options. In the same way, Western (1998) found that students whose parents had high educational levels had access to a variety of resources which assisted and facilitated to participate in university studies. Ahmed (1991) arrived at the result that out of 56 candidates who had qualified the competitive examination for public sector jobs at the Khyber Pakhtunkhwa Provincial Public Commission Pakistan, 30 of the candidates had parents with Bachelor and above educational qualifications. Krashen (2005) found that students whose parents are educated score higher on standardized tests as compared to those whose parents were not educated.

Poverty is a crucial and destructive factor that affects student's academic achievement 
negatively. There is inversely relation of parental low income with the student's academic achievement. Sum and Fogg (1991) conducted a study and found that poor students are graded in the $19^{\text {th }}$ percentile on assessments while students from a mid-upper income family are ranked in the $66^{\text {th }}$ percentile on assessments. In data from the Early Childhood Longitudinal Study (ECLS) measuring academic achievement of kindergarten students on the ECLS reading achievement assessment, low income students scored at about the $30^{\text {th }}$ percentile, middle income students scored at about the $45^{\text {th }}$ percentile, and upper income students scores at about the $70^{\text {th }}$ percentile (Rowan et al., 2004). Klebanov et al. (1994) concluded that both mothers' education and family income were the main predictors of the physical atmosphere and learning experiences in the home but that mothers' education alone was predictive of parental warmth. Similarly, Smith et al. (1997) found that the combination of family income and parental education with children's academic attainment was mediated by the home environment. The mediation effect was stronger for maternal education than for family income. Thus, they proposed that education might be connected to specific achievement behaviors in the home e.g., reading, playing. Maurin (2002) stated that there are so many reasons that why parental income is potentially a very important determinant of the performance of children at school. The main reason is may be that rich parents can buy better food, better housing and medical care. In other words, they can purchase more of all the basic goods and services that support children's development and assist them to perform well at school. Imagining that the parental demand for these specific goods and services really increases with parental income, we should examine a significant impact of income on children's performance. Krueger (2004) reviews various contributions supporting the view that financial limitations and constrains significantly impact on educational attainment of a student.

Parental occupation has a signification affect on the academic achievement of students. It plays a remarkable role in students' academic achievement. Good parental occupation has a positive effect on the academic achievement of students. The Saifi and Mehmood (2011) study the effects of socioeconomic status on student's achievement and they used income, parent's education and occupation, material possessed at home, transport and servants as the indicators of socioeconomic status and data were analyzed by applying percentages. The findings revealed that parental education and occupation and facilities at home affect the student's achievement.

\section{Statement of the Problem}

The study under research was specially designed to know the effects of parental socioeconomic status on the academic achievement of students. Therefore the statement of the problem was designed as "Effects of Parental Socioeconomic Status on the Academic Achievement of Secondary School Students in Karak District, Pakistan”.

\section{Objectives of the Study}

The objectives of the study were: 


\section{Macrothink}

International Journal of Human Resource Studies

ISSN 2162-3058

2012, Vol. 2, No. 4

1. to find out the effect of parental socioeconomic status on the academic achievement of secondary school students

2. to determine the effect of parental educational level on the academic achievement of secondary school students

3. to find out the effect of parental occupational level on the academic achievement of secondary school students and

4. to suggest workable recommendations for the enhancement of the students' academic achievement.

\section{Hypotheses of the Study}

To achieve the above objectives, the researchers decided to develop the following hypotheses:

1. There is significant effect of parental socio-economic status on the academic achievement of secondary school students

2. There is significant effect of parental income level on the academic achievement of secondary school students

3. There is significant effect of father's educational level on the academic achievement of secondary school students

4. There is significant effect of mother's educational level on the academic achievement of secondary school students

5. There is significant effect of father's occupational level on the academic achievement of secondary school students

6. There is significant effect of mother's occupational level on the academic achievement of secondary school students

\section{Research Methodology}

\section{Participants}

All the students at secondary school level in District Karak (Khyber Pakhtunkhwa) Pakistan constituted the population of the study. The study was delimited to only sixty government boys' high schools in District Karak. The study was further delimited to the students of $10^{\text {th }}$ Class. In order to represent adequate sample, 25 students from each school were selected as a sample randomly. The size of the sample is explained as under:

\begin{tabular}{cccccc}
\hline \multicolumn{2}{c}{ No. of Government Boys Schools } & & $\begin{array}{c}\text { No. of Students from each } \\
\text { School }\end{array}$ & Total \\
\cline { 1 - 3 } Rural & Urban & Total & & Schn \\
\hline 45 & 15 & 60 & & 25 & $\mathbf{1 5 0 0}$ \\
\hline
\end{tabular}

\section{Research Instrumentation}

As the study was descriptive type in nature and a self-developed structured questionnaire was used for the collection of data. It was composed of six different closed ended questions. 


\section{Macrothink}

\section{Pilot Testing}

It is a reality that the results of a research study depend upon the authentication and validation of a research instrument. Therefore, it was imperative to conduct pilot testing in order to investigate the weaknesses, misconceptions and ambiguities of the questionnaire. After the conduction of pilot testing, final version of the questionnaire was developed and finalized in the light of suggestions given by the experts.

\section{Validity and Reliability}

It is necessary to ensure the reliability and accuracy of the research instruments. Reliability is the degree of consistency that an instrument or data collection procedure demonstrates, whereas validity is the quality of the collection procedure of the data that enables it to measure what it intends to measure. Validity of the questionnaire was checked by five experts in the field of education having doctorate degrees. Cronbach's alpha was used to estimate the reliability of questionnaire. The reliability coefficient was found to be 0.87 . The Cronbach's alpha formula is given as under:

$$
\alpha=\frac{N \cdot \bar{C}}{\bar{V}+(N-1) \cdot \bar{C}}
$$

Where

$$
\begin{aligned}
& \mathrm{N}=\text { Total number of respondents } \\
& \bar{C}=\text { Average inter-item covariance } \\
& \bar{V}=\text { Average variance }
\end{aligned}
$$

\section{Data Collection}

In order to collect data, the researchers personally visited to the sample schools and distributed the questionnaires among participants. They were told to give appropriate response. In this way data was collected.

\section{Statistical Analysis of the Data}

After collection of data, the data was organized, tabulated and analyzed. Chi-square and percentage were used for the statistical treatment of the data. The following formula for chi square was used for the analysis of data.

$$
\mathrm{X}^{2}=\sum \frac{\left[\left(f_{o}-f_{e}\right)^{2}\right]}{f_{e}}
$$

Where

$$
\sum=\text { Sum of } \quad f_{o}=\text { Observed Frequency } f_{e}=\text { Expected frequency }
$$

\section{Standard or Scales for the Verification of Hypotheses}

For the verification of hypotheses, the following self-developed scales were developed: 
1. Parent's socioeconomic status was classified into three categories i.e. "High SES", "Middle SES" and "Low SES".

2. Parent's income was classified into three categories i.e. "Upper Income", "Middle Income" and "Low Income".

\section{Upper income}

It was used for those parents whose monthly income was Rs.30000 or above.

\section{Middle income}

It was used for those parents whose monthly income was between Rs.20000 and less than Rs.300000.

\section{Low income}

It was used for those parents whose monthly income was Rs.10000 and less than Rs.20000.

3. Father's and mother's education was classified into three categories i.e. "S.S.C \& Below" "Intermediate" and "Graduation \& Above".

4. Father and mother's occupation was classified into four classes i.e. Class I, Class II, Class III and Class IV.

Class - I Bureaucrats, Doctors, Professors, administrators, Engineers, Businessman, Professionals and Gazetted Officers, in short all those officials who work in BPS-16 to BPS-22

Class - II Non-Gazetted Official, School Teachers blow BPS-16, Clerks, Office Assistants, Steno Graphers, In short all those officials who work in BPS-7 to BPS-15

Class - III Class IV Officials, Airman, constables, Army constables, Drivers, In short official who work in BPS-1 to BPS-6.

Class - IV Jobless, Laborers, transport workers and related workers

5. The students were classified into three categories i.e., High Achievement, Normal Achievement and Low Achievement regarding their academic achievement in the annual examination 2012 conducted by BISE Kohat.

High Achievement

Normal Achievement

Low Achievement
It contains those students who have gotten first division $(60 \%$ \& above) in their annual examination 2012 conducted by BISE Kohat.

It contains those students who have gotten $2^{\text {nd }}$ division $(45 \%$ to $59 \%$ ) in their annual examination 2012 conducted by BISE Kohat. It contains those students who have gotten $3^{\text {rd }}$ division $(45 \%$ \& below) in their annual examination 2012 conducted by BISE Kohat.

\section{Analysis and Interpretation of Data}

The study was specially designed to explore the effects of parental socioeconomic status on the academic achievement of secondary school students. The study was survey type and a self-developed structured questionnaire was designed. Data was collected through personal visits. After collection of data, it was organized, tabulated and analyzed. Percentage and chi square were applied for the statistical analysis of the data. The whole process is 
explained in detail as below:

H 1: There is significant effect of parental socio-economic status on the academic achievement of secondary school students

Table 01: Showing the effect of parental socio-economic status on the academic achievement of secondary school students

\begin{tabular}{|c|c|c|c|c|c|}
\hline Level of Achievement & High SES & Middle SES & Low SES & $\mathbf{N}$ & $\chi^{2}$ \\
\hline High Achievement & $\begin{array}{c}227 \\
(51.4 \%)\end{array}$ & $\begin{array}{c}136 \\
(30.8 \%)\end{array}$ & $\begin{array}{c}079 \\
(17.9 \%)\end{array}$ & 442 & \multirow{4}{*}{$265.8 *$} \\
\hline Normal Achievement & $\begin{array}{c}240 \\
(31.9 \%)\end{array}$ & $\begin{array}{c}316 \\
(42.0 \%)\end{array}$ & $\begin{array}{c}196 \\
(26.1 \%)\end{array}$ & 752 & \\
\hline Low Achievement & $\begin{array}{c}023 \\
(07.5 \%) \\
\end{array}$ & $\begin{array}{c}084 \\
(27.5 \%) \\
\end{array}$ & $\begin{array}{c}199 \\
(65.0 \%) \\
\end{array}$ & 306 & \\
\hline Total & 490 & 536 & 474 & 1500 & \\
\hline
\end{tabular}

*Significant $(p=.000<0.05) \quad$ df $=4 \quad$ table value of $\chi^{2}$ at 0.05 level $=9.488$

Table 01 indicates that the calculated value of $\chi^{2}$ was found to be 265.8 which is statistically significant because it is greater than the table value of $\chi^{2}$ at 0.05 level. Hence the hypothesis that "there is significant effect of parental socio-economic status on the academic achievement of secondary school students" is not rejected. It means that parental socioeconomic status effects students' academic achievement significantly. It was further illustrated by the following bar graph:

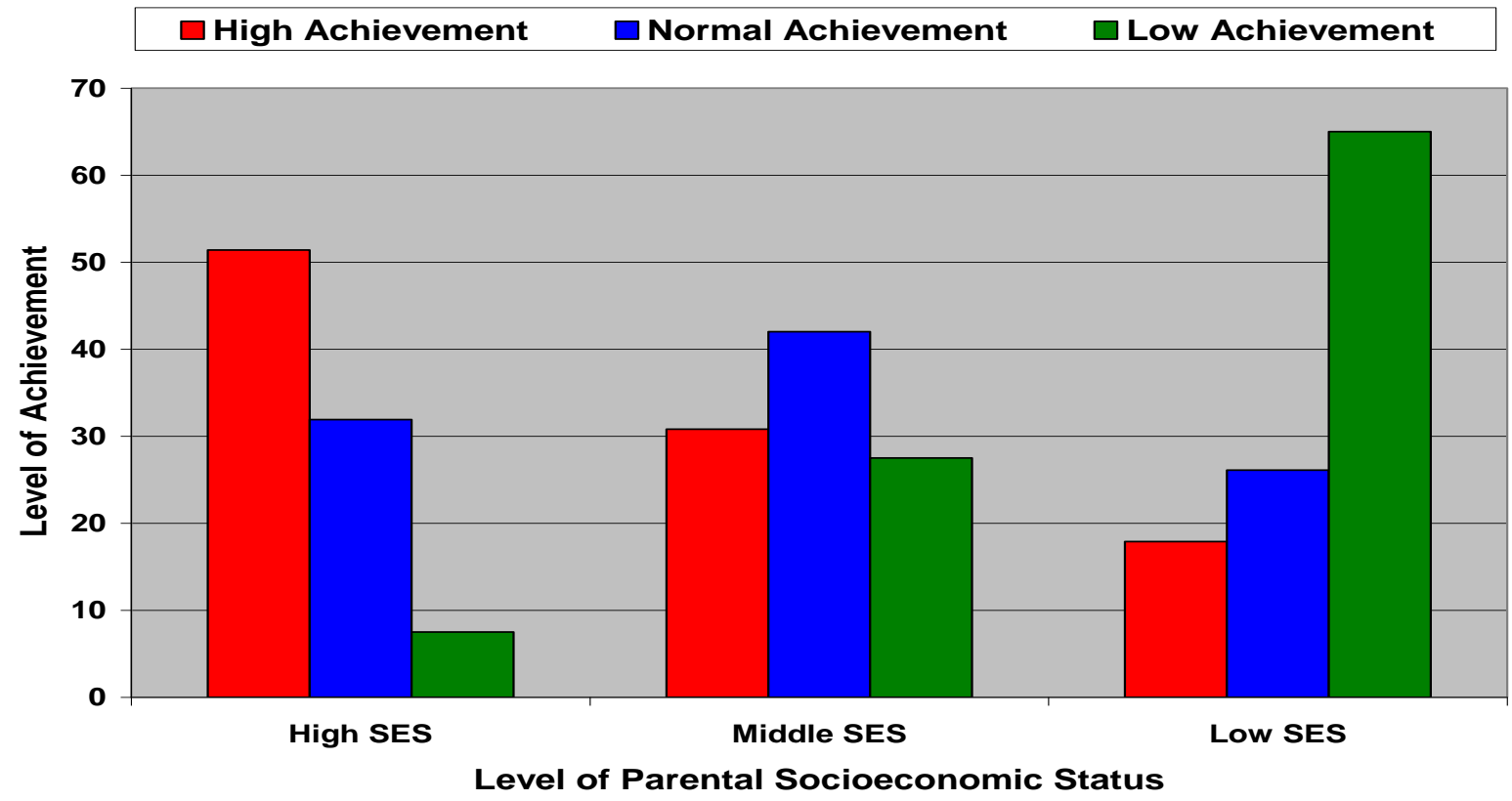

Figure 1: Showing the Responses of Students 
H 2: There is significant effect of parental income on the academic achievement of secondary school students

Table 02: Showing the effect of parental income on the academic achievement of secondary school students:

\begin{tabular}{|c|c|c|c|c|c|}
\hline Level of Achievement & $\begin{array}{c}\text { Upper } \\
\text { Income }\end{array}$ & $\begin{array}{l}\text { Middle } \\
\text { Income }\end{array}$ & $\begin{array}{c}\text { Low } \\
\text { Income }\end{array}$ & $\mathbf{N}$ & $\chi^{2}$ \\
\hline High Achievement & $\begin{array}{c}216 \\
(48.9 \%)\end{array}$ & $\begin{array}{c}127 \\
(28.7 \%)\end{array}$ & $\begin{array}{c}099 \\
(22.4 \%)\end{array}$ & 442 & \multirow{4}{*}{ 173.1* } \\
\hline Normal Achievement & $\begin{array}{c}234 \\
(31.1 \%)\end{array}$ & $\begin{array}{c}324 \\
(43.1 \%)\end{array}$ & $\begin{array}{c}194 \\
(25.8 \%)\end{array}$ & 752 & \\
\hline Low Achievement & $\begin{array}{c}038 \\
(12.4 \%)\end{array}$ & $\begin{array}{c}096 \\
(31.4 \%)\end{array}$ & $\begin{array}{c}172 \\
(56.2 \%)\end{array}$ & 306 & \\
\hline TOTAL & 488 & 547 & 465 & 1500 & \\
\hline
\end{tabular}

*Significant $(p=.000<0.05)$ df $=4 \quad$ table value of $\chi^{2}$ at 0.05 level $=9.488$

Table 02 illustrates that the calculated value of $\chi^{2}$ was found to be 173.1 which is statistically significant because it is greater than the table value of $\chi^{2}$ at 0.05 level. Hence the hypothesis that "There is significant effect of parental income on the academic achievement of secondary school students" is not rejected. It means that parental income affects students' academic achievement significantly. It was further explained by the following bar graph:

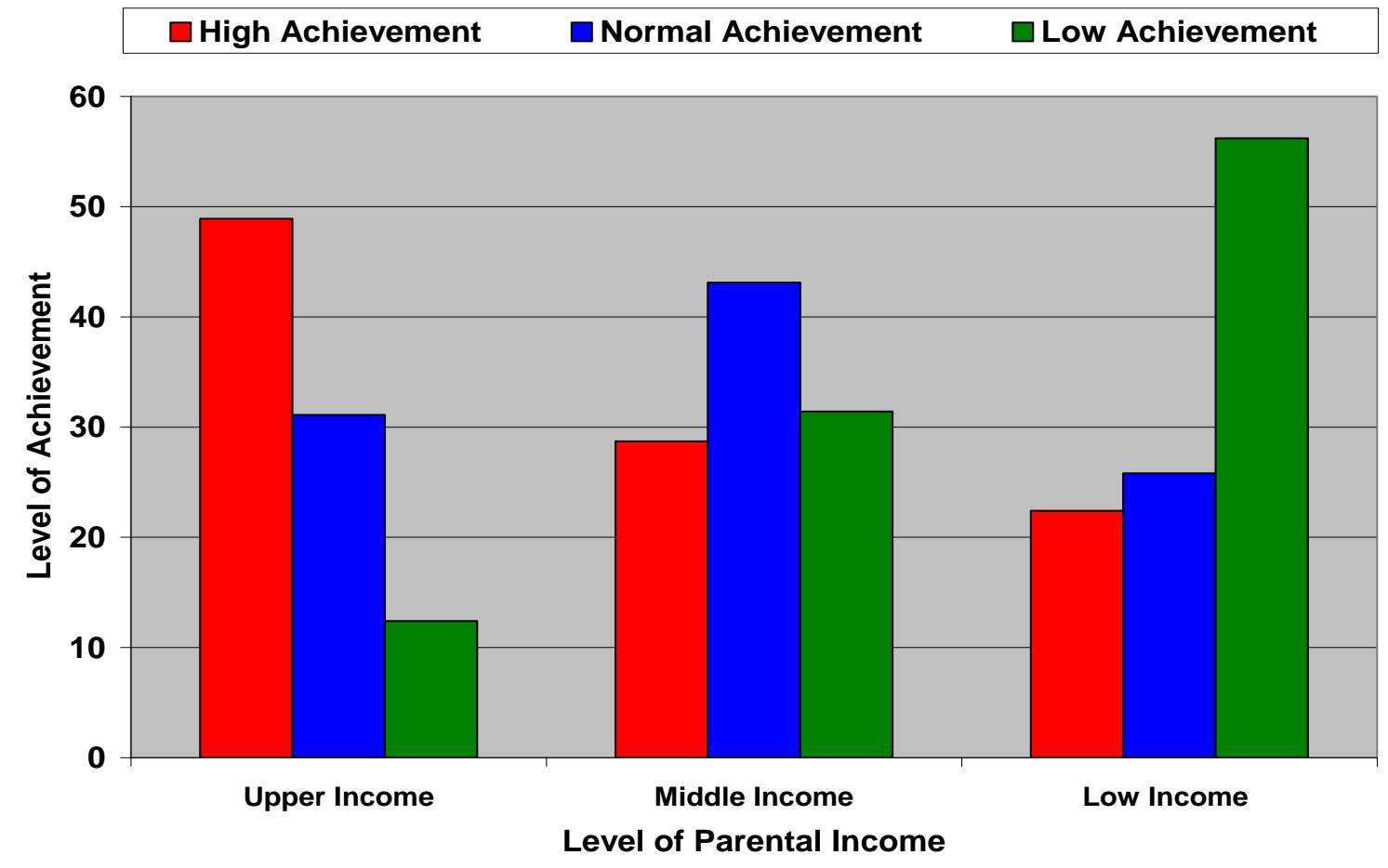


Figure 2: Showing the Responses of Students

H 3: There is significant effect of father's educational level on the academic achievement of secondary school students:

Table 03: Showing the effect of father's educational level on the academic achievement of secondary school students:

\begin{tabular}{|c|c|c|c|c|c|}
\hline \multirow[b]{2}{*}{ Level of Achievement } & \multirow{2}{*}{$\begin{array}{c}\text { S.S.C } \\
\text { \& Below }\end{array}$} & \multicolumn{4}{|c|}{ Graduation } \\
\hline & & Intermediate & \& Above & $\mathbf{N}$ & $\chi^{2}$ \\
\hline High Achievement & $\begin{array}{c}083 \\
(18.8 \%)\end{array}$ & $\begin{array}{c}145 \\
(32.8 \%)\end{array}$ & $\begin{array}{c}214 \\
(48.4 \%)\end{array}$ & 442 & \\
\hline Normal Achievement & $\begin{array}{c}174 \\
(23.1 \%)\end{array}$ & $\begin{array}{c}341 \\
(45.3 \%)\end{array}$ & $\begin{array}{c}237 \\
(31.5 \%)\end{array}$ & 752 & $256.2 *$ \\
\hline Low Achievement & $\begin{array}{c}186 \\
(60.8 \%)\end{array}$ & $\begin{array}{c}107 \\
(35.0 \%)\end{array}$ & $\begin{array}{c}013 \\
(04.2 \%)\end{array}$ & 306 & \\
\hline TOTAL & 443 & 593 & 464 & 1500 & \\
\hline
\end{tabular}

Table 03 illustrates that the calculated value of $\chi^{2}$ was found to be 256.2 which is statistically significant because it is greater than the table value of $\chi^{2}$ at 0.05 level. Hence the hypothesis that "There is significant effect of father's educational level on the academic achievement of secondary school students" is not rejected. It shows that father's educational level affects the academic achievement of students. It was further explained by the following bar graph:

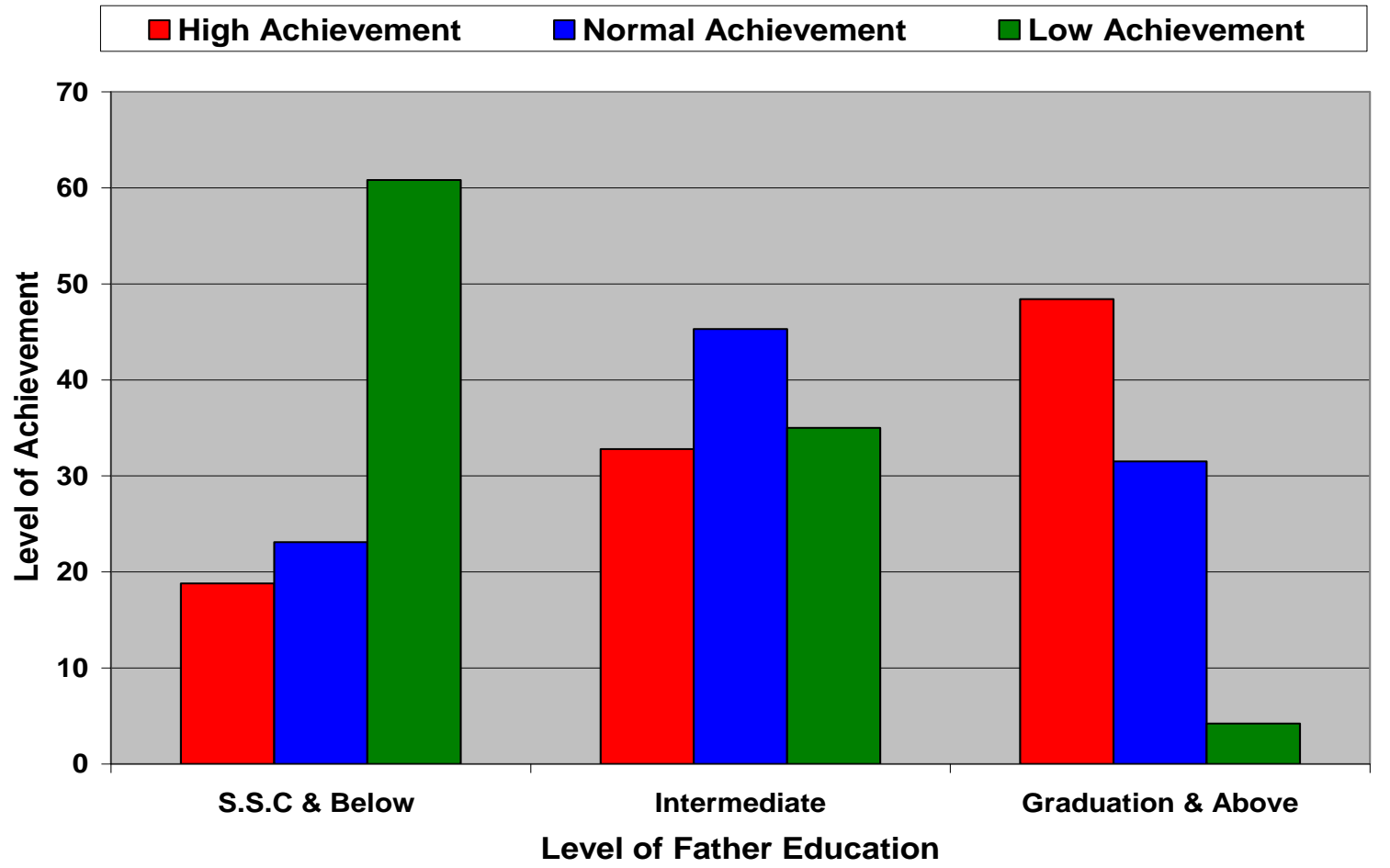


Figure 3: Showing the Responses of Students

H 4: There is significant effect of mother's educational level on the academic achievement of secondary school students

Table 04: Showing the effect of mother's educational level on the academic achievement of secondary school students:

\begin{tabular}{|c|c|c|c|c|c|}
\hline Level of Achievement & $\begin{array}{c}\text { S.S.C } \\
\text { \& Below }\end{array}$ & Intermediate & $\begin{array}{c}\text { Graduation } \\
\text { \& Above }\end{array}$ & $\mathbf{N}$ & $\chi^{2}$ \\
\hline High Achievement & $\begin{array}{c}076 \\
(17.2 \%)\end{array}$ & $\begin{array}{c}161 \\
(36.4 \%)\end{array}$ & $\begin{array}{c}205 \\
(46.4 \%)\end{array}$ & 442 & \multirow{4}{*}{$300.2 *$} \\
\hline Normal Achievement & $\begin{array}{c}187 \\
(24.9 \%)\end{array}$ & $\begin{array}{c}361 \\
(48.0 \%)\end{array}$ & $\begin{array}{c}204 \\
(27.1 \%)\end{array}$ & 752 & \\
\hline Low Achievement & $\begin{array}{c}202 \\
(66.0 \%)\end{array}$ & $\begin{array}{c}096 \\
(31.4 \%)\end{array}$ & $\begin{array}{c}008 \\
(02.6 \%) \\
\end{array}$ & 306 & \\
\hline TOTAL & 465 & 618 & 417 & 1500 & \\
\hline
\end{tabular}

Table 04 illustrates that the calculated value of $\chi^{2}$ was found to be 300.2 which is statistically significant because it is greater than the table value of $\chi^{2}$ at 0.05 level. Hence the hypothesis that "There is significant effect of mother's educational level on the academic achievement of secondary school students" is not rejected. It depicts that mother's educational level has positive effect on the academic achievement of students. It was further illustrated by the following bar graph:

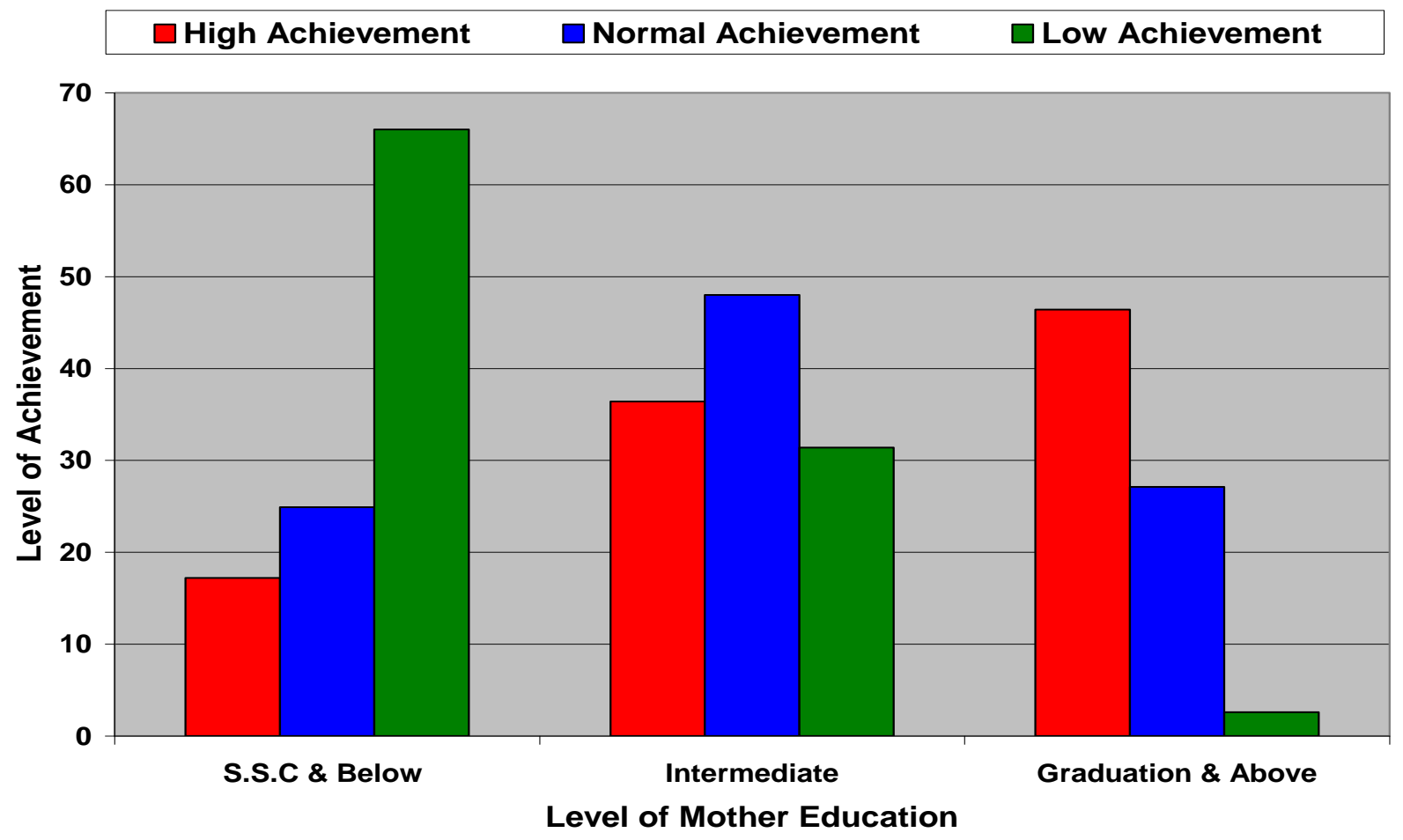


Figure 4: Showing the Responses of Students

H 5: There is significant effect of father's occupational level the academic achievement of secondary school students:

Table 05: Showing the effect of father's occupational level on the academic achievement of secondary school students:

\begin{tabular}{ccccccc}
\hline Level of Achievement & Class I & Class II & Class III & Class IV & N & $\chi^{\mathbf{2}}$ \\
\hline High Achievement & 167 & 134 & 078 & 063 & $\mathbf{4 4 2}$ & \\
& $(37.8 \%)$ & $(30.3 \%)$ & $(17.6 \%)$ & $(14.3 \%)$ & & \\
Normal Achievement & 121 & 386 & 139 & 106 & $\mathbf{7 5 2}$ & \\
& $(16.1 \%)$ & $(51.3 \%)$ & $(18.5 \%)$ & $(14.1 \%)$ & & $\mathbf{3 3 0 . 7} *$ \\
Low Achievement & 015 & 045 & 129 & 117 & $\mathbf{3 0 6}$ & \\
& $(04.9 \%)$ & $(14.7 \%)$ & $(42.2 \%)$ & $(38.2 \%)$ & & \\
TOTAL & $\mathbf{3 0 3}$ & $\mathbf{5 6 5}$ & $\mathbf{3 4 6}$ & $\mathbf{2 8 6}$ & $\mathbf{1 5 0 0}$ &
\end{tabular}

*Significant $(p=.000<0.05) \quad \mathrm{df}=6 \quad$ table value of $\chi^{2}$ at 0.05 level $=12.592$

Table 05 illustrates that the calculated value of $\chi^{2}$ was found to be 330.7 which is statistically significant because it is greater than the table value of $\chi^{2}$ at 0.05 level. Hence the hypothesis that "There is significant effect of father's occupational level on the academic achievement of secondary school students" is not rejected. It shows that father's occupational level affect the academic achievement of students. It was further explained by the following bar graph:

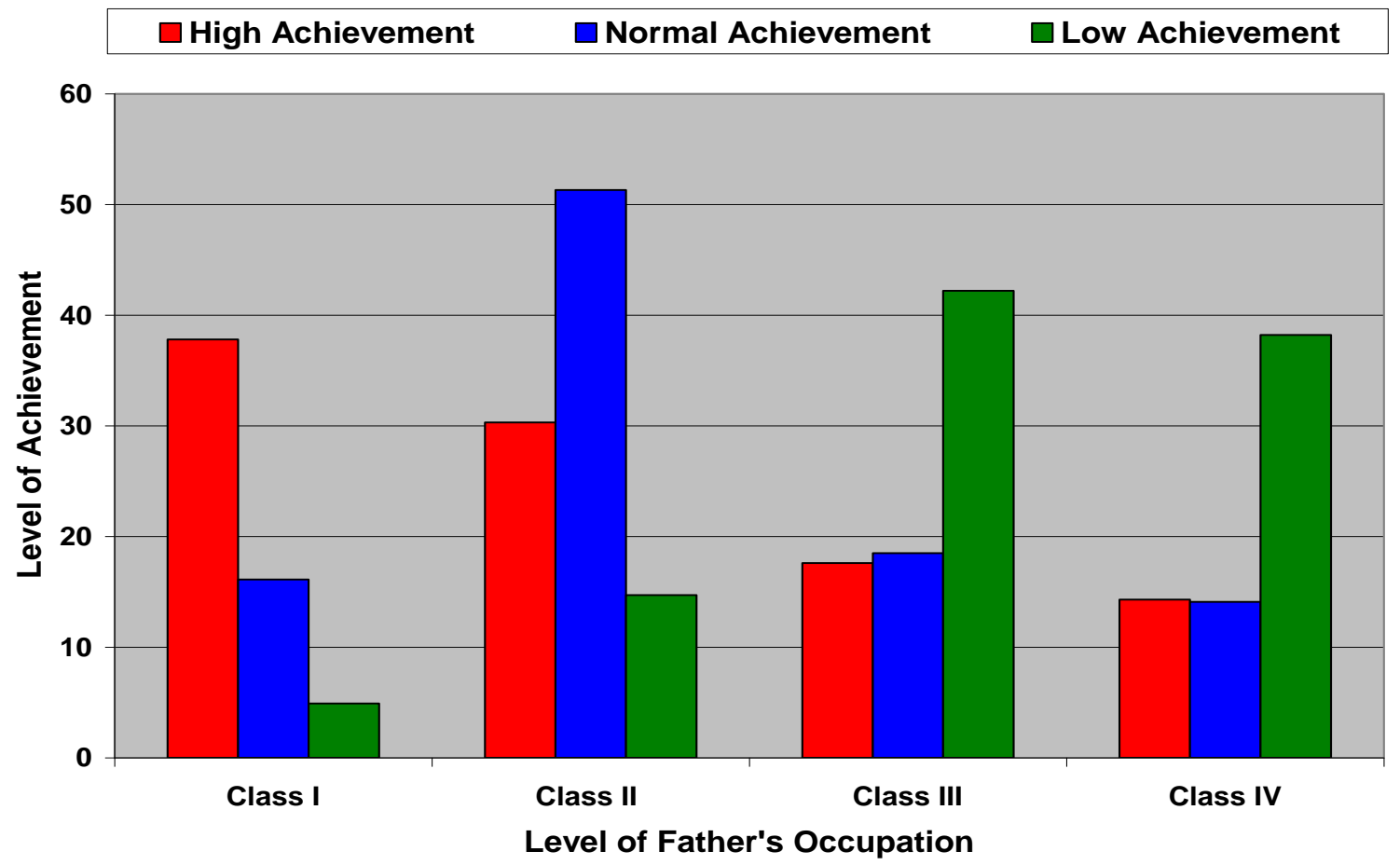

Figure 5: Showing the Responses of Students 
H 6: There is significant effect of mother's occupational level on the academic achievement of secondary school students:

Table 06: Showing the effect of mother's occupational level on the academic achievement of secondary school students

\begin{tabular}{ccccccc}
\hline Level of Achievement & Class I & Class II & Class III & Class IV & N & $\boldsymbol{\chi}^{\mathbf{2}}$ \\
\hline High Achievement & 116 & 142 & 099 & 085 & $\mathbf{4 4 2}$ & \\
& $(26.2 \%)$ & $(32.1 \%)$ & $(22.4 \%)$ & $(19.2 \%)$ & & \\
Normal Achievement & 125 & 372 & 149 & 106 & $\mathbf{7 5 2}$ & \\
& $(16.6 \%)$ & $(49.5 \%)$ & $(19.8 \%)$ & $(14.1 \%)$ & & \multirow{3}{*}{${ }^{230.7}$} \\
Low Achievement & 009 & 036 & 126 & 135 & $\mathbf{3 0 6}$ & \\
& $(02.9 \%)$ & $(11.8 \%)$ & $(41.2 \%)$ & $(44.1 \%)$ & & \\
TOTAL & $\mathbf{2 5 0}$ & $\mathbf{5 5 0}$ & $\mathbf{3 7 4}$ & $\mathbf{3 2 6}$ & $\mathbf{1 5 0 0}$ & \\
\hline
\end{tabular}

*Significant $(p=.000<0.05) \quad \mathrm{df}=6 \quad$ table value of $\chi^{2}$ at 0.05 level $=12.592$

Table 06 illustrates that the calculated value of $\chi^{2}$ was found to be 280.2 which is statistically significant because it is greater than the table value of $\chi^{2}$ at 0.05 level. Hence the hypothesis that "There is significant effect of mother's occupational level on the academic achievement of secondary school students" is not rejected. It shows that father's employment level affects students' academic achievement. It was further explained by the following bar graph:

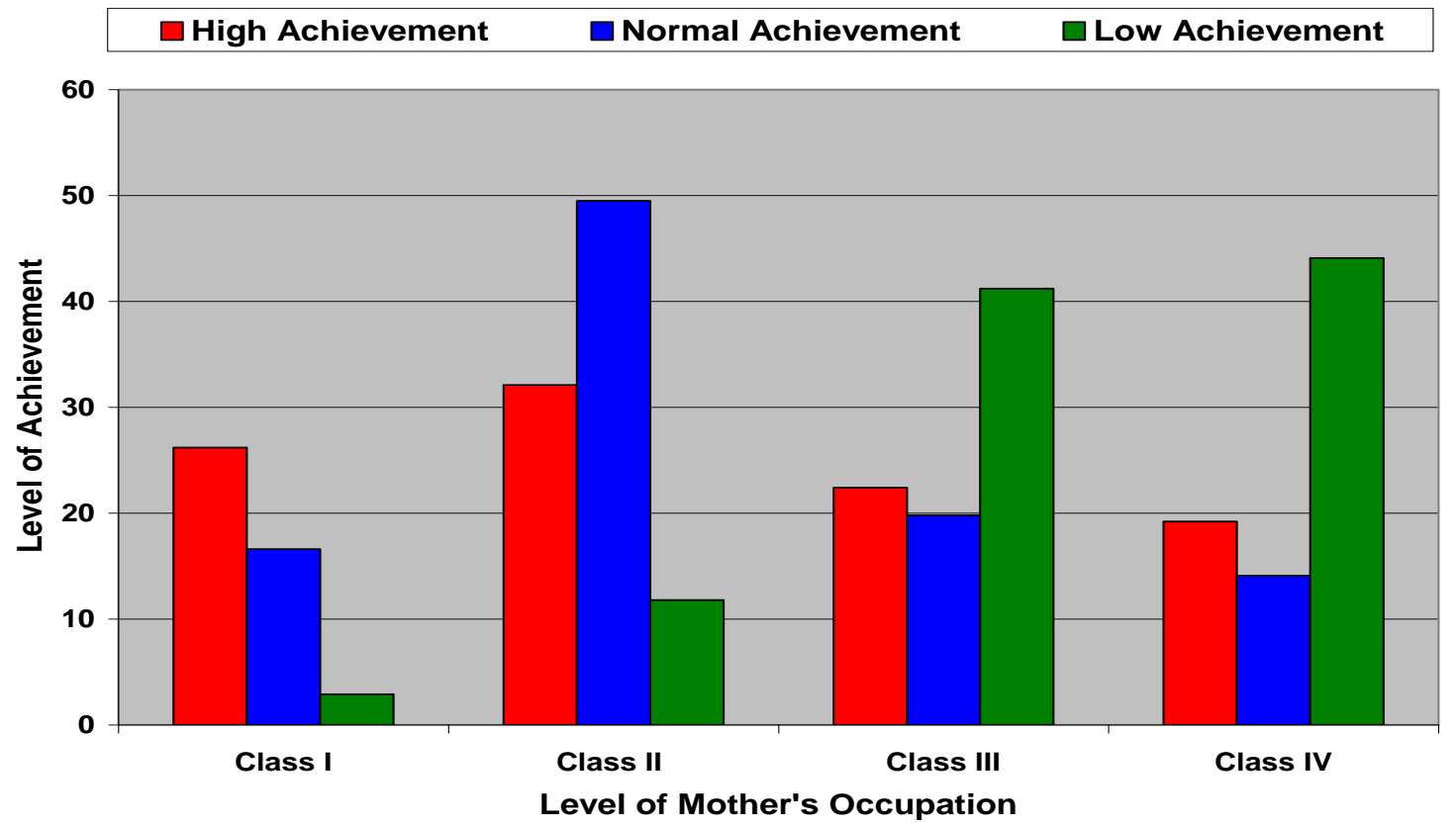

Figure 6: Showing the Responses of Students 


\section{Conclusions}

After statistical analysis of the data, the researchers arrived at the following conclusions: It was found that:

1. There is significant effect of parental socio-economic status on the academic achievement of secondary school students. It was found that students from low socioeconomic status have lower academic achievement as compared to the academic achievement of students from higher socioeconomic status.

2. There is significant effect of parental income level on the academic achievement of secondary school students. The students showed good academic performance whose parental income was more as compared to those students whose parental income was low.

3. There is significant effect of parental educational level on the academic achievement of secondary school students. Parental educational levels revealed the clearest patterns of variation in the academic achievement of students. Students showed higher academic achievement whose father and mother were more educated as compared those students whose father and mother were not educated or less educated.

4. There is significant effect of father and mother occupational level on the academic achievement of secondary school students. Students performed better whose father and mother occupation was better as compared to those students whose father's occupation was not better.

\section{Concluding Remarks}

Parental socioeconomic status is a vital factor that effect academic achievement of students significantly. The results of the study reveal that students have shown excellent performance in the annual examination 2012 conducted by Board of Intermediate \& Secondary Education Kohat whose parental socioeconomic status was strong and high. It was also come to surface that academic achievement of a student is directly proportional to the parental income, education and occupation. That is why it is right to say that high socioeconomic status of the parents plays a fundamental and crucial role in the enhancement of their children's academic achievement

\section{Recommendations}

Keeping in view the conclusions, the researchers give the following recommendations:

1. As it was found that low socio-economic status badly influences student's academic performance and important variable to influence students, academic achievement therefore, it is strongly recommended that unemployment should be controlled. Poor students should be provided scholarships, free books and other stationary. In addition, it is also recommended that government should take steps to raise socioeconomic status of people.

2. The study revealed that mothers' education is very important for the academic achievement of students therefore it is recommended that government should take necessary action to increase and encourage female education. 
3. Educational facilities play a fundamental role in improving the educational outcomes of students therefore it is strongly recommended that government should ensure the provision of educational facilities for students.

4. Majority of the parents are not aware of the home environment that influences student's academic achievement and therefore it is strongly recommended that parents should be made aware of the importance of home environment in their children academic achievement. For this purpose, teachers, educationists and leaders may play their role to make them aware of the importance of home environment for their student's academic achievement.

5. Parents should be informed that they can improve the education of their children through encouragement, provision of educational facilities and participation.

6. Majority of the parents are not educated (Suleman et al., 2012) therefore it is strongly recommended that financially strong parents should arranged home tuition for their children in order to improve their children academic performance.

7. Parent's involvement and participation has a significant effect on the academic performance of the students (Suleman et al., 2012) therefore it is strongly recommended that interaction and communication between the parents and teachers should be strengthened for better results of the students.

8. Parents are advised to pay full attention on their children education at home. They should male a time table for their children regarding homework and studies. In this way their academic performance will be improved.

\section{Recommendations for Further Research Studies}

1. It is recommended that this type of research study should be conducted in other districts and provinces.

2. It is also recommended that this type of research study should be conducted at elementary, higher secondary and tertiary level.

3. It is further recommended that this type of research study should be conducted on female population at elementary, secondary, higher secondary and tertiary levels.

\section{References}

Adams, A. (1996). Even Basic Needs of Young are not Met. Retrieved from http://tc.education.pitt.edu/library/SelfEsteem

Adewale, A. M. (2002). Implication of parasitic infections on school performance among school-age children. Ilorin Journal of Science Education. Vol.2pp. 78-81.

Ahmed, M. (1991). The NWFP Public Service Commission Annual Report. Peshawar: Government Printing Press.

Amato, P. R. (1987). Family processes in one-parent, stepparent and intact families the child's point of view. Journal of Marriage and the Family. 49 (3) 27-37.

Coleman, J. S., et al. (1966). Equality of Educational Opportunity. Washington, D.C.: United States Government Printing Office.

Caldas, S. J., and Bankston, C. (1997). Effects of school population socioeconomic status on individual academic achievement. Journal of Educational Research, 90, 268-277. 
Duke, N. (2000). For the rich it's richer: Print environments and experiences offered to first-grade students in very low- and very high-SES school districts. American Educational Research Journal, 37(2), 456-457.

Duncan, G. J., and K. A. Magnuson. (2005). Can Family Socioeconomic Resources Account for Racial and Ethnic Test Score Gaps? The Future of Children. The Woodrow Wilson School of Public and International Affairs: Princeton University. Washington, D.C.: The Brookings Institution.

Eamon, M. K. (2005). Social-demographic, school, neighborhood, and parenting influences on academic achievement of Latino young adolescents. Journal of Youth and Adolescence, 34(2), 163-175.

Farooq, M.S, Chaudhry, A. H., Shafiq, M. \& Berhanu, G. (2011). Factors Affecting Students' Quality of Academic performance: A case of secondary school level. Journal of Quality and Technolgy Mangement, Vol-VII, Issue II, 01-14.

Graetz, B. (1995). Perspectives on socioeconomic status in Ainley, J., Graetz, B., Long, M. \& Batten, M. Socioeconomic Status and School Education. Canberra: Australian Government Publishing Service, pp5-22.

Heyneman, S. P. (2005). Student background and students achievement: What is the question? American Journal of Education, 112 (November), 1-9.

Jeynes, W. H. (2002). Examining the effects of Parental absence on the academic achievement of adolescents: the challenge of controlling for family income. Journal of Family and Economic Issues 23 (2).

Klebanov, P. K., Brooks-Gunn, J., \& Duncan, G. J. (1994). Does neighborhood and family poverty affect mothers' parenting, mental health, and social support? Journal of Marriage and the Family, 56, 441-455.

Krashen, S. (2005). The hard work hypothesis: Is doing your homework enough to overcome the effects of poverty? Multicultural Education, 12 (4), 16-19.

Krueger, A. B. (2004). "Inequality, too much of a good thing”, in J.J. Heckmand and A.B.Krueger (eds), Inequality in America, MIT Press

Kruse, K. (1996). The Effects of a low socioeconomic environment on the student's academic achievement. ( ERIC Document Reproduction Service No. ED 402380).

Maurin, E. (2002). The impact of parental income on early schooling transitions: A re examination using data over three generations. Journal of Public Economics 85 (2002) $301-332$

Morakinyo, A. (2003). Relative efficacy of systematic desensitization, self statement monitoring and flooding on students test anxiety. Unpublished PhD. Thesis. University of Ibadan.

Muller, C. (1883). "Parent Ties to the School and Community and Student Academic Performance." Paper presented at the conference on Sociology of Education, Asilomar. CA.

Oakes, J. M., \& Rossi, P. H. (2002). The measurement of SES in health research: Current practice and steps toward a new approach. Social Science and Medicine, 56, 769-784.

Peters H. E, \& Mullis, N. C. (1997). The role of family income and sources of income in adolescent achievement. In Duncan, Brooks-Gunn (Eds.), Consequences of Growing 
Up Poor. New York: Russell Sage Foundation, pp 340-381.

Parson, R. D., Stephanie, L. H. \& Deborah, S. (2001). Educational Psychology: A Practitioner-Researcher Model of Teaching. Singapore: Thomson Learning Inc

Rouse, C. E., \& Barrow, L. (2006). U.S. elementary and secondary schools: Equalizing opportunity or replicating the status quo? The Future of Children 16(2), 99-123.

Rowan, B., Cohen D. K, \& Raudenbush, S. W. (2004). Improving the educational outcomes of students in poverty through multidisciplinary research and development. http://www.isr.umich.edu/carss/about/Prospectus.pdf

Saifi, S. \& Mehmood, T. (2011). Effects of socio-economic status on students achievement. International Journal of Social Sciences \& Education, 1(2), 119-128

Sirin, S. R. (2005). Socioeconomic status and academic achievement: A meta-analytic review of research. Review of Educational Research, 75, 417-453.

Smith, J. R., Brooks-Gunn, J., \& Klebanov, P. K. (1997). Consequences of living in poverty for young children's cognitive and verbal ability and early school achievement. In G. J. Duncan \& J. Brooks-Gunn (Eds.), Consequences of growing up poor (pp.132-189). New York: Russell Sage Foundation

Stevenson, D. L. \& Baker, D. P. (1987). “The Family-School Relation and the Child's School Performance”. Child Development 58: 1348-57.

Suleman, Q., Aslam, H. D, Shakir, M., Akhtar, S., Hussain, I., \& Akhtar, Z. (2012). Effects of Family Structure on the Academic Performance of Students at Elementary Level in District Karak, Khyber Pakhtunkhwa (Pakistan). Journal of Sociological Research, Vol. 3, No.2

Sum, A. M, \& Fogg W. N. (1991). The adolescent poor and the transition to early adulthood. In Edelman P, Ladner J (Eds.), Adolescence \& Poverty: Challenge for the 1990s. Lanham, MD: Center for National Policy Press. pp 37-110.

Western, J.S. (1983) Social Inequality in Australian Society South Melbourne: MacMillan.

Wenglinsky, H. (1998). Does it compute? Princeton, NJ: Educational Testing Service, Policy Information Center.

White, K. R. (1982). The relation between socioeconomic status and academic achievement. Psychological Bulletin, 91(3) 461-481.

Williams, T. (1987). Participation in Education, Australian Council for Educational Research, Hawthorn.

Williams, T. M, Long, P. C, and Hayden, M. (1993). Year 12 in the 1980s, AGPS, Canberra.

Website Used:

en.wikipedia.org/wiki/Socioeconomic_status

http://nces.ed.gov/programs/coe/glossary/s.asp

http://std.about.com/od/glossary/g/sesgloss.htm 